\title{
Tanzania
}

Priscilla C. Reining (Catholic Univ.): Kinship, marriage and the family among the Haya; John Howell (Wisconsin): Isanzu oral literature; J. Gallagher (Dar es Salaam): Oral history of the Songea region; Melvin E. Page (Howard Univ.): Development of Central Tanganyikan trade up to $1884 ; S$. Rogers (Dar es Salaam): The political history of the Chagga.

Uganda

Joan E. Vincent (Columbia): Social change in a multi-ethnic community (Teso District); Charles M. Good (Chicago): Rural market systems in Western Uganda; T. T. Poleman (Makerere): Nutritional implications of rapid urbanization in Uganda.

Upper Volta

Thomas Peterson (Los Angeles, California): A generative grammar of More.

Zambia

Stuart A. Marks (Michigan State): Ecology of the Valley Bisa.

\section{University College Dar es Salaam: The Hans Cory Collection}

THE papers of the late Hans Cory, formerly Ethnographer to the Government of Tanganyika, are deposited in the library of University College Dar es Salaam. Dr. Norman H. Miller of Michigan State University, who has been sorting and classifying the papers, has now published an inventory in the African Studies Bulletin of the A.S.A., Boston (vol. ix, no. 2, September 1968, pp. 195-21 3). The material falls into seven general categories: (I) local government, including native administration, constitution, and reform; (2) agricultural economics and land tenure; (3) magic, religion, secret societies, and related medical practices; (4) arts and crafts; (5) ethnography and tribal history; (6) customary law; (7) language. There are also files of plant samples, drawings, paintings, and song texts. The regional foci of much of the work are on the ethnic groups around Lake Victoria, particularly the Sukuma, Haya, Zinza, Kerewe, and Kuria. The peoples of central and western Tanzania, the Nyamwezi, Gogo, Nyaturu-Rimi, Ha, and Fipa are represented in the collection, and there are some data on the eastern and coastal ethnic groups, particularly the Pare, Luguru, Zaramo, and Sambaa. Apart from a few monographs dealing with the Ngoni and Hehe, most ethnic groups of the southern regions of the country are not treated. From the mid y950s Cory was in charge of a major government project to record and codify the customary law of several ethnic groups, and at the time of his death in 1962 studies of the Sukuma, Nyamwezi, Zinza, Sambaa, Haya, Gogo, Nyaturu, and Hangaza had been completed.

\section{'Bolletino della Associazione degli Africanisti Italiani'}

THE Association of Italian Africanists was founded in 1967. The President is Carlo Giglio, Professor of the History and Institutions of the Afro-Asian Countries in the University of Pavia. The first number of its bulletin (January-March 1968) sets out the constitution of the association and includes an account of past and future Italian historical studies in Africa and a list of sources for the history of Africa south of the Sahara.

\section{'Etudes Congolaises'}

LA revue Études Congolaises fut editée de 196I à 1967 par l'Institut National d'Études Politiques (INEP) de Kinshasa, mais depuis I 968 elle est devenue la revue des sciences humaines de l'Office National de la Recherche et du Développement (B.P. 3 I I9, Kinshasa-Kalina), créée par l'ordonnance du Président de la République en 1967. Actuellement la revue publie, par an, quatre numéros de iso pages chacun. 